Review on Agriculture and Rural Development 2019 vol. 8 (1-2) ISSN 2677-0792

\title{
THE EFFECT OF SEED DENSITY, VARIETY AND SOIL INOCULANT ON THE YIELD OF SOYBEAN
}

\author{
IstVán Kristó ${ }^{1}$, Marianna VÁlyi Nagy ${ }^{1}$, Péter Jakab ${ }^{2}$, Melinda TaR ${ }^{1}$ \\ ${ }^{1}$ National Agricultural Research and Innovation Centre, Department of Field Crops \\ Research, Alsó Kikötő sor 9., H-6726 Szeged, Hungary \\ ${ }^{2}$ University of Szeged Faculty of Agriculture, Andrássy str. 15., H-6800 \\ Hódmezővásárhely, Hungary \\ kristo.istvan@noko.naik.hu
}

\begin{abstract}
The research was established in one growing season (2018), in 4 repeats, on 10 square meter random layout plots in the research farm of the Department of Field Crops Research of National Agricultural Research and Innovation Centre, in Szeged-Öthalom.

In our investigation we used two different seeding rates (40 and 60 seeds $\mathrm{m}^{-2}$ ) on two soybean varieties (Pannónia kincse, Bahia). This study was carried out in inoculated field soil and non-inoculated field soil. We determined the yield and evaluated our results with ANOVA according to the different seeding density and varieties.

From the results of our one-year survey, we could determine that Bahia had a higher yield than Pannonia kincse, which could be proved at 5\% level of significance. Based on this data, we can see that the $60 \mathrm{seeds}^{-}$ ${ }^{2}$ plots produced higher yields than the lower seed density $\left(40\right.$ seeds $\left.\mathrm{m}^{-2}\right)$ plots. The results show that soybean yields increased as a result of soil inoculation.
\end{abstract}

Keywords: soybean, seed density, variety, soil inoculant, yield

\section{INTRODUCTION}

The main goals of crop production experiments are the practical adaptability and the development of profitability. The environmental and landscape protection, but also climatic changes are becoming more and more important, so beside cultivation purposes, particularly the conditions of production site should be taken into consideration by the farmers. In order to maintain sustainability, genotypes with constant yield production and adaptability, as well as high quality parameters are needed.

There are adequate soil conditions in Hungary. Almost $50 \%$ of the area of Hungary is arable land, which is unique in Europe regarding its size and quality. The most important natural resource of the country is the ability of agricultural production.

Soybean is one of the most important pulses in Hungary. Although the growing area of soybean is increasing in Hungary, unfortunately our country still needs to import it. Therefore, any research that supports the production of soybean in Hungary can be cause economic benefits. VARGA (1996) determined that ordinary cultivation factors (crop rotation, nutrition, cultivation etc.) had barely changed the yield of soybean, except for the inoculation, which gives yield increase in $15-20 \%$ as a result. By KURNIK (1970), inoculation of soybean influenced not only the quantity, but also the quality of yield. According to EGLI (1988), the mechanisms responsible for the observed responses to changing plant density are not well understood. Sowing density and row spacing have a major influence on soybean yields and yield components (COX AND CHERNEY, 2010; LIU ET AL., 2010). Several authors ascribe great importance to the relationship of plant density and variety selection (COOPER, 1989; BOARD AND HARVILLE, 1994; BALL ET AL., 2000). Inoculating soybean with bacteria and mycorrhiza fungi also contributes to nutrient uptake and utilization (Young ET AL., 1986; KoutrouBAS ET AL., 1989; FATIMA ET AL., 2007). 
The aim of our study was to determine the effect of seed density and soil inoculants on the yield of two soybean varieties.

\section{MATERIAL AND METHOD}

The research was established in one growing season (2018), in 4 repeats, on 10 square meter random layout plots in the research farm of the Department of Field Crops Research of National Agricultural Research and Innovation Centre, in Szeged-Öthalom.

In our investigation, we used two different seeding rates (40 and 60 seeds $\mathrm{m}^{-2}$ ) in two soybean varieties (Pannónia kincse, Bahia). This study was carried out in inoculated field soil and non-inoculated field soil. Soil inoculation prepared with a composition containing bacteria and mycorrhiza fungi. We determined the yield and evaluated our results with ANOVA according to the different seeding density and varieties. Figure 1 shows the distribution of precipitation in the vegetative period of soybean in 2018 .

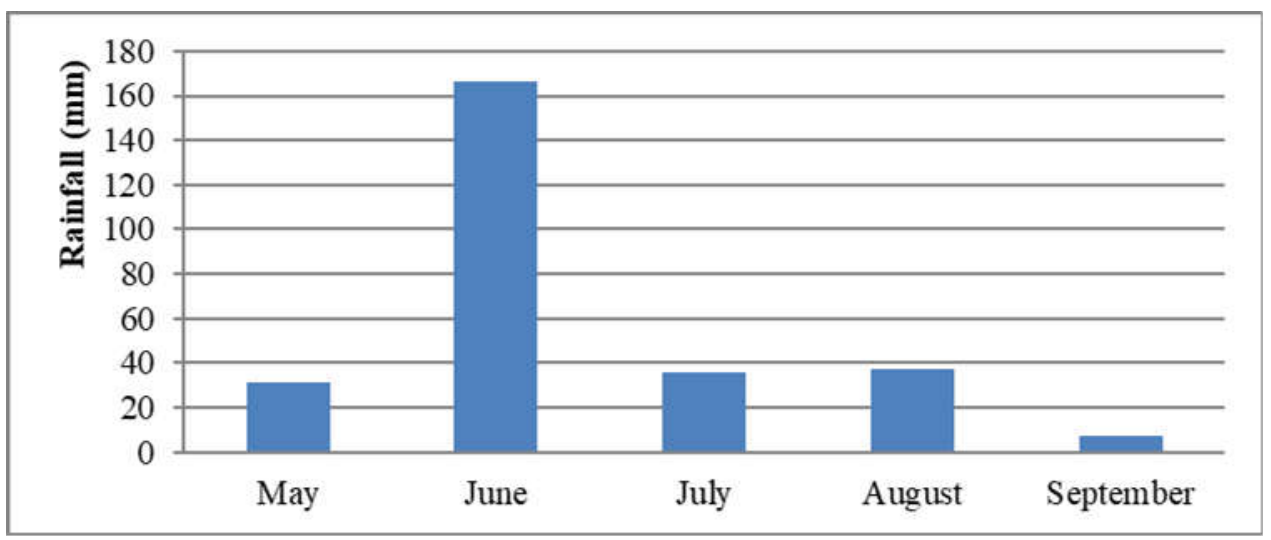

Figure 1. The distribution of precipitation in the vegetative period of soybean

\section{RESULTS}

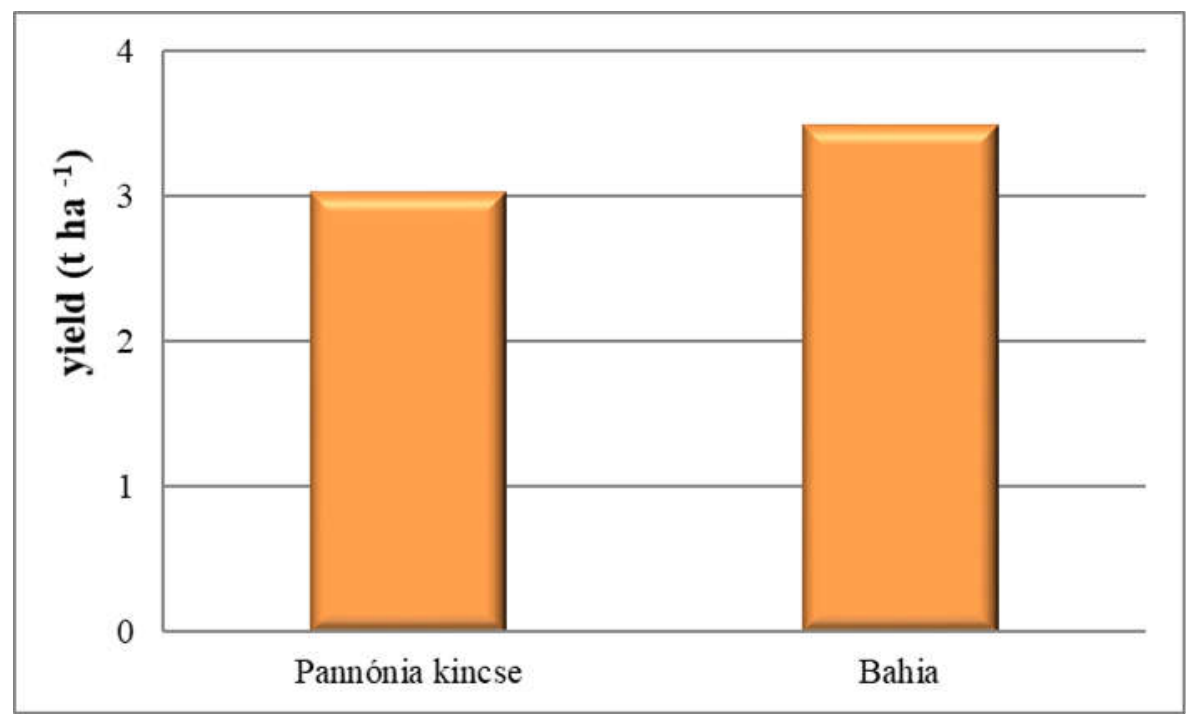

Figure 2. Effect of varieties on the yield of soybean

In our experiment, the yield of Bahia soybean variety was more than $15 \%$ higher than the yield of Pannonia kincse (Figure 2). 


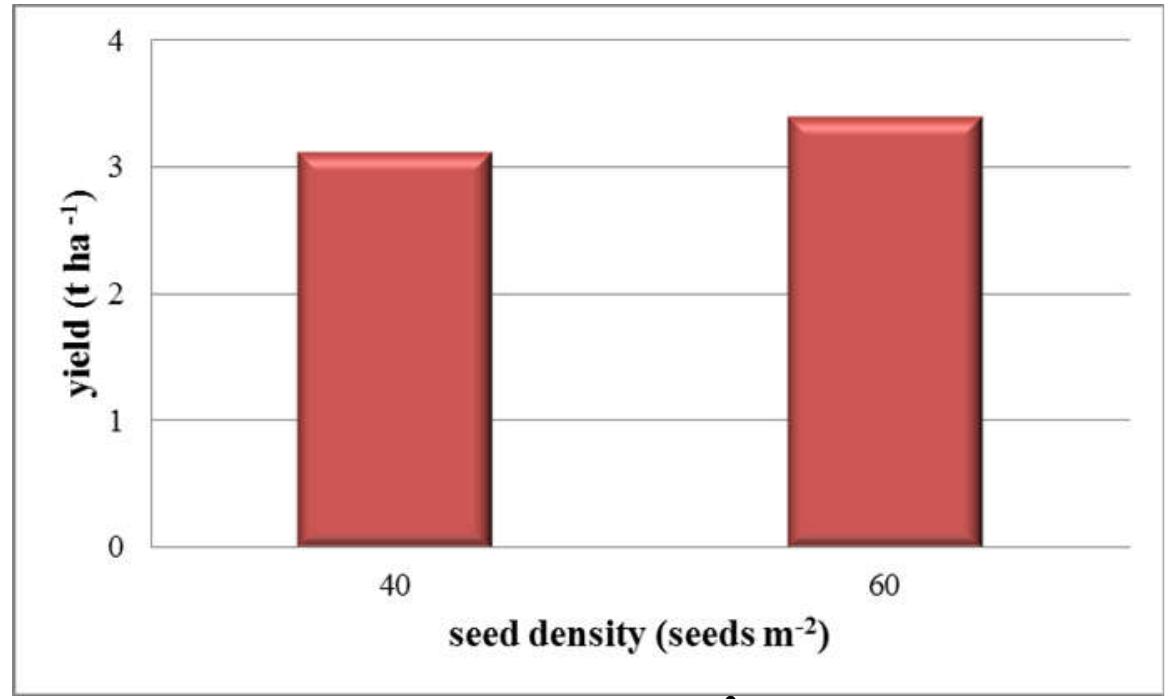

Figure 3. Effect of seed density (seeds $\mathrm{m}^{-2}$ ) on the yield of soybean

In terms of sowing density, the higher seed density parcels had almost $9 \%$ higher yield than the smaller seed density parcels (Figure 3).

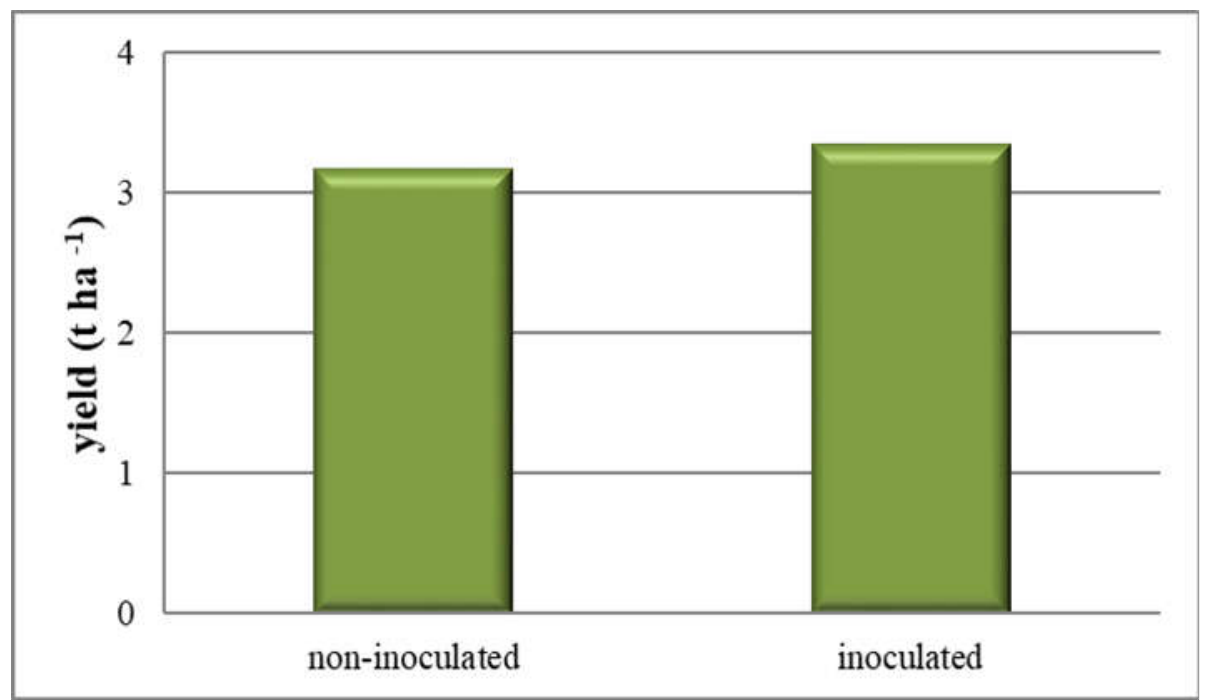

Figure 4. Effect of soil treatment on the yield of soybean

Soil inoculation increased soybean yield by almost $5 \%$ - in the average variety and seed density (Figure 4).

In the case of the non-inoculated plots, the average seed number of the yield of Bahia soybean variety was $14 \%$ higher than the yield of Pannonia kincse, it has significant difference (Table 1). In the average of varieties, the 60 seeds $\mathrm{m}^{-2}$ plots yield were $9 \%$ higher than 40 seeds $\mathrm{m}^{-2}$ plots, but we couldn't prove this statistically.

In the inoculated plots, by examining the average seed number, it can be determined that the yield of Bahia soybean variety was $17 \%$ higher than the yield of Pannonia kincse, it has significant difference. In the average of varieties, the yield of the 60 seeds $\mathrm{m}^{-2}$ plots was $8 \%$ higher than in the 40 seeds $\mathrm{m}^{-2}$ plots, and we were able to prove this statistically. 
Table 1. Effect of variety and seed number on yield of soybean, in inoculated and non-inoculated soil

\begin{tabular}{|c|c|c|c|c|c|}
\hline Inoculation & $\begin{array}{l}\text { Seed number } \\
\left(\text { Seeds } \mathbf{m}^{-2} \text { ) }\right.\end{array}$ & Pannónia kincse & Bahia & Average & LSD $_{5 \%}$ \\
\hline \multirow{4}{*}{ Non-inoculated } & 40 & 2.77 & 3.29 & 3.03 & \multirow{2}{*}{0.29} \\
\hline & 60 & 3.14 & 3.47 & 3.30 & \\
\hline & Average & 2.95 & 3.38 & \multirow{2}{*}{\multicolumn{2}{|c|}{0.29}} \\
\hline & LSD $_{\mathbf{5}} \%$ & 0.29 & & & \\
\hline \multirow{4}{*}{ Inoculated } & 40 & 2.95 & 3.47 & 3.21 & \multirow{2}{*}{0.24} \\
\hline & 60 & 3.23 & 3.73 & 3.48 & \\
\hline & Average & 3.09 & 3.60 & \multirow{2}{*}{\multicolumn{2}{|c|}{0.24}} \\
\hline & $\mathbf{L S D}_{\mathbf{5} \%}$ & 0.24 & & & \\
\hline
\end{tabular}

Table 2. Effect of variety and inoculant on the yield of soybean, at different seed densities

\begin{tabular}{|c|c|c|c|c|c|}
\hline 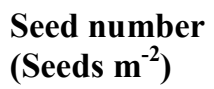 & Inoculation & Pannónia kincse & Bahia & Average & $\mathbf{L S D}_{\mathbf{5} \%}$ \\
\hline \multirow{4}{*}{40} & Non-inoculated & 2.77 & 3.29 & 3.03 & \multirow{2}{*}{0.17} \\
\hline & Inoculated & 2.95 & 3.47 & 3.21 & \\
\hline & Average & 2.86 & 3.38 & \multirow{2}{*}{\multicolumn{2}{|c|}{0.17}} \\
\hline & LSD $_{5 \%}$ & 0.1 & & & \\
\hline \multirow{4}{*}{60} & Non-inoculated & 3.14 & 3.47 & 3.30 & \multirow{2}{*}{0.24} \\
\hline & Inoculated & 3.23 & 3.73 & 3.48 & \\
\hline & Average & 3.18 & 3.60 & \multirow{2}{*}{\multicolumn{2}{|c|}{0.34}} \\
\hline & $\mathbf{L S D}_{\mathbf{5} \%}$ & \multicolumn{2}{|c|}{0.34} & & \\
\hline
\end{tabular}

On the 40 seeds $\mathrm{m}^{-2}$ parcels, it can be determined that the yield of Bahia soybean variety was $18 \%$ higher than the yield of Pannonia kincse, it has significant difference (Table 2). In the case of the average of varieties, the yield of the the inoculated plots was $6 \%$ higher than that of the non-inoculated plots which is significant difference.

On the 60 seeds $\mathrm{m}^{-2}$ parcels, by examining the varieties, it can be determined that the yield of Bahia soybean variety was $13 \%$ higher than the yield of Pannonia kincse, it has significant difference. In the average of varieties, the yield of the inoculated plots was 5\% higher than in the non-inoculated plots, this difference we couldn't prove statistically.

Table 3. Effect of inoculant and seed density variety on yield of soybean varieties

\begin{tabular}{|c|c|c|c|c|c|}
\hline \multirow{2}{*}{ Variety } & Seed number & \multirow{2}{*}{ Non-inoculated } & \multirow{2}{*}{ Inoculated } & \multirow{2}{*}{ Average } & \multirow{2}{*}{$\mathbf{L S D}_{5 \%}$} \\
\hline & $\left(\right.$ Seeds $\left.\mathbf{m}^{-2}\right)$ & & & & \\
\hline \multirow{4}{*}{ Pannónia kincse } & 40 & 2.77 & 2.95 & 2.86 & \multirow{2}{*}{0.12} \\
\hline & 60 & 3.14 & 3.23 & 3.18 & \\
\hline & Average & 2.95 & 3.09 & \multirow{2}{*}{\multicolumn{2}{|c|}{0.34}} \\
\hline & $\mathbf{L S D}_{5 \%}$ & \multicolumn{2}{|l|}{0.12} & & \\
\hline \multirow{4}{*}{ Bahia } & 40 & 3.29 & 3.47 & 3.38 & \multirow{2}{*}{0.38} \\
\hline & 60 & 3.47 & 3.73 & 3.60 & \\
\hline & Average & 3.38 & 3.60 & \multirow{2}{*}{\multicolumn{2}{|c|}{0.53}} \\
\hline & $\mathbf{L S D}_{5 \%}$ & 0.38 & & & \\
\hline
\end{tabular}


In the case of the Pannonia kincse soybean variety, by examining soil treatments on the average seed number shows that the yield of the inoculated plots was $5 \%$ higher than in the non-inoculated plots, which has significant difference (Table 3). On the average soil inoculation, the yield of 60 seeds $\mathrm{m}^{-2}$ plots was $11 \%$ higher than in the 40 seeds $\mathrm{m}^{-2}$ plots, which has significant difference.

In the case of the Bahia soybean variety, by examining soil treatments of the average seed number shows that the yield of the inoculated plots was $7 \%$ higher than in the noninoculated plots, which we couldn't prove statistically. On the average soil inoculation, the yield of the 60 seeds $\mathrm{m}^{-2}$ plots was $7 \%$ higher than in the 40 seeds $\mathrm{m}^{-2}$ plots, which has not significant difference.

\section{CONCLUSIONS}

From the results of our one-year survey, we could determine that the effect of the different seed density, variety, and soil inoculation characteristics shows high level of differences in the yield of soybean. According to our results, the treatment of seed density has surplus crop up to $7-11 \%$. The 60 seeds $\mathrm{m}^{-2}$ plots produced higher yields than the lower seed density $\left(40\right.$ seeds $\left.\mathrm{m}^{-2}\right)$ plots. In our study, the right variety choice results surplus yield at a level of $13-18 \%$. Bahia has higher yield than the Pannonia kincse, which could be proved at $5 \%$ level of significance. Our results shows that soil inoculants increase the yield of soybean by $5-7 \%$ - depending on other treatment.

\section{REFERENCES}

Afzal, A., Bano, A., Fatima, M. (2010): Higher soybean yield by inoculation with Nfixing and P-solubilizing bacteria. Agronomy for Sustainable Development 30: 487-495.

BALL, R.A., PURCELL, L.C., VORIES, E.D., (2000): Optimizing soybean plant population for a short- season production system in the Southern USA. Crop Science 40: 757-764.

BOARD, J.E., HARVILLE, B.G., (1994): A criteria for acceptance of narrow-row culture in soybean. Agronomy Journal 86: 1103-1106.

COOPER, R.L. (1989): High-yield-system-place (HYSIP) concept for soybean production. Journal Production Agriculture 2: 321-324.

Cox, W.J., Cherney, J.H. (2010): Growth and Yield Responses of Soybean to Row Spacing and Seeding Rate. Agronomy Journal 103(1): 123-128.

EGLI, D.B. (1988): Plant density and soybean yield. Crop Science 28(6): 977-981.

FATIMA, Z., ZiA, M., CHAUdHARY, M.F. (2007): Interactive effect of Rhizobium strains and $\mathrm{P}$ on soybean yield, nitrogen fixation and soil fertility. Pakistan Journal of Botany 39(1): 255-264.

Koutroubas, S.D., Papakosta, D.K., Gagianas, A.A. (1989): The importance of early dry matter and nitrogen accumulation in soybean yield. European Journal of Agronomy 9(1): 1-10.

KURNIK, E. (1970): Étkezési és abraktakarmányhüvelyesek termesztése. Akadémiai Kiadó, Budapest. 499 p.

LiU, B., LiU, X.B., Wang, C., Jin, J., Herbert, S.J., Hashemi, M. (2010): Responses of soybean yield and yield components to light enrichment and planting density. International Journal of Plant Production 4: 1-10.

VArga, J. (1996): Szója. Pp. 474-491. In.: Bocz E: Szántóföldi növénytermesztés. Mezőgazda Kiadó, Budapest. 886 p.

YounG, C.C., JuAnG, T.C., GuO, H.Y (1986): The effect of inoculation with vesiculararbuscular mycorrhizal fungi on soybean yield and mineral. Plant and Soil 95(2): 245-253. 